\title{
Preparing Tomorrow's School Leaders with a Standards-Based, Prescriptive Curriculum
}

\author{
David L. Gray \\ Associate Professor of Education \\ The University of South Alabama \\ Tel: (251) 380-2618 E-mail: dgray@usouthal.edu
}

\begin{abstract}
The No Child Left Behind (NCLB) Act of 2001 holds public schools in the United States accountable for increased student achievement and adequate yearly progress (AYP). Schools that do not make AYP for three consecutive years are subject to stringent sanctions. Principals, teachers, and students are under tremendous pressure to demonstrate increased achievement each year. State Boards of Education are insisting that school leaders have knowledge about curriculum and instruction in addition to the managerial skills that were the hallmarks of educational administration programs in years past. Colleges that prepare prospective principals are redesigning their instructional leadership programs to ensure that they are prescriptive, standards-based, and curriculum-focused to meet NCLB's rigorous requirements.
\end{abstract}

Keywords: Instructional Leadership, Principal Leadership, Standards-Based Curriculums, Prescriptive Approach to Curriculum Development, Adequate Yearly Progress

The No Child Left Behind (NCLB) Act of 2001 with its provisions for high-stakes testing and sanctions against poorly-performing schools has stimulated curriculum reform in America's public K-12 and post-secondary institutions. Significant changes have been made by colleges of education that are discarding principal-as-manager professional development models in favor of standards-based curriculums that will empower tomorrow's principals to lead students to increased academic achievement, which NCLB defines as making Adequate Yearly Progress (AYP). Changes in leadership curriculums were based on decisions made by local boards of education to replace criterion-referenced tests in public schools with a national, norm-referenced assessment that compels third through twelfth grade teachers to teach a prescriptive curriculum focused on attaining that goal.

Schools are under tremendous pressure to make AYP. Test preparation receives so much emphasis that teachers have reduced or eliminated instruction in subjects other than those to be tested. Abrams \& Madaus (2003) discovered that "in some states, $80 \%$ of the elementary schools spend $20 \%$ of their instructional time preparing for the end-of-grade tests" (p. 32). Klein (2005) noted that students "are coached on how to take standardized tests, subjected to pep rallies to get them revved up to do their best on high-stakes tests, treated to breakfast at school on the day of testing, given sugar snacks just before testing, and presented with gift certificates to stores in the local mall when they do well on the state tests" (pp. 51-52).

All students are required to make (AYP) by 2014 in reading, mathematics, science, and social studies. Results, however, have been discouraging. Guilfoyle (2006) noted that, "over 19,000 schools nationwide failed to make AYP in 2002-2003; more than 11,000 were identified as being in need of improvement" (p. 10). Hoff (2008) reported that, "almost 30,000 schools in the United States failed to make adequate yearly progress under the No Child Left Behind Act in the 2007-08 school year," and "half those schools missed their achievement goals for two or more years, putting almost one in five of the nation's public schools in some stage of a federally mandated process to improve student achievement."

Unintended consequences of NCLB's emphasis on increased student achievement include its de facto redefinition of the principal's role as an instructional leader and a correlative adjustment in the effort school leaders must make to help teachers improve their teaching skills. Gaziel (1995) reported "A serious discrepancy between the amount of time principals spend doing important tasks and the time they think they should spend on them" (p. 184). Attaining AYP, the product of data-driven instruction, means that principals must have the knowledge and ability to analyze student test data to make decisions about curriculum, instruction, and professional development, a condition unique for administrators who were trained as managers, not as instructional leaders.

Linda Darling-Hammond (1997) emphasized a principal-leader's importance, however, by writing, "when principals work to provide the conditions and means for teacher learning, student achievement increases" (p. 57). NCLB, however, 
defines achievement in a narrow context and relies on school officials to alter curriculums and practices that nhibit a school's ability to attain AYP. Changes are prescriptive, not experimental.

Revising an outdated model begins with developing a shared vision of the knowledge and abilities instructional leaders should have. Jazzar and Algozzine (2006) concede that "it is difficult to define the role of a principal as the instructional leader" (p. 106), but "the educational reform movement of the last two decades has focused a great deal of attention on that role" (p. 104).

Recognizing that teachers alone were unable to create the conditions needed to attain AYP, state boards of education investigated discrepancies between the principal's roles as building manager and instructional leader. They discovered that many administrators did not have adequate knowledge about curriculums nor the skills to analyze data to make decisions that would improve instruction, in part because the programs that had prepared them to become school leaders were grounded in the wrong curriculum model.

The governor of Alabama formed a task force of teachers, civic leaders, and community representatives to create a vision of effective school leadership. The state department of education published the group's findings as standards with accompanying descriptions of what principals should know and be able to do to satisfy a prescriptive curriculum's first requirement, to select appropriate learning objectives.

The second step in designing a prescriptive curriculum is to select learning experiences that are useful in attaining those objectives. Ralph Tyler (1949) advised curriculum theorists that, "a student must have experiences that give him an opportunity to practice the kind of behavior implied by the objective" (p. 65). Each of the state's 14 post-secondary institutions with principal-preparation programs was encouraged to redesign its curriculum to include the newly-approved standards and to ensure continuity, sequence, and integration in clinical experiences that would give future principals opportunities to observe, practice, and lead teachers and students toward improved academic achievement.

The next step was to organize the learning experiences to reinforce each other to produce a cumulative effect (Tyler, $\mathrm{p}$. 83). Selected standards were woven through the curriculum because of their importance in developing effective principals. As examples, leadership students will be expected to demonstrate ethical behavior, to communicate effectively, and to use technology appropriately during and after their program.

Evaluation is the final step in creating a prescriptive curriculum. Care must be given to include assessments that measure changes in student behavior. Traditional post-secondary evaluations focus on work products or tests that, at best, infer student understanding. The impetus for changing an Instructional Leadership curriculum, however, is to instill more appropriate knowledge, skills and attitudes in prospective school leaders than management-oriented curriculums in years past.

T. J. Sergiovanni (2009) suggested dispositions, or the professional attitudes and beliefs that administrators display during interactions with others and toward their job, either unite a school organization or cause it to languish. Appropriate dispositions encourage its members to "transcend ordinary competence for extraordinary commitment. and require that people be transformed from subordinates to followers, which requires a different kind of theory and practice" (p. 89). Principal-as-manager curriculums failed to provide opportunities for students to develop a perspective about leadership. They emphasized instead the managerial duties school administrators are expected to perform. The vagaries of curriculum, servant-leadership, and professional attitudes were subordinated to more exacting knowledge, such as school law and finance. NCLB's underpinnings, however, require principals to lead students to greater academic achievements, a process rooted in effective communication skills, successful interpersonal relations, and shared school governance.

School districts in every state are beginning to recognize instructional leadership's connection to student achievement. NCLB, a national trend toward standards-based curriculums, and pressure from state and local boards of education for improved student learning are moving those responsible for preparing school leaders to refine their efforts. Principal-preparation programs unable or unwilling to reform their curriculums are likely to fall by the wayside. Resnick (2002) emphatically noted that, "it is reasonable to expect principals to learn instructional leadership competencies" (p. 2) that include shared governance with school stake holders, meaningful interactions with students, and using data to make decisions about teaching and learning.

Marsh and Willis (2007) described curriculum theorizing as a general process involving individuals in activities requiring them to be sensitive to emerging patterns of phenomena, to identify common patterns and issues, and to relate those patterns to one's own teaching context (p. 100). Although Tyler discouraged theorists from using his syllabus as a manual for curriculum construction (p. 1), his prescriptive approach met the needs of Instructional Leadership curriculum designers at the University of South Alabama. Careful evaluation of student achievement and the redesigned program over time will determine whether or not a standards-based, prescriptive curriculum for instructional leaders is effective. 


\section{References}

Abrams, I.M., \& Madaus, G.F. (2003). The lessons of high-stakes testing. Educational Ledership, 61 (32), 31-35.

Darling-Hammond, L. (1997). The right to learn: A blueprint for creating schools that work. San Francisco: Jossey-Bass.

Gaziel, H. (1995, November). Managerial work patterns of principals at high- and average-performing Israeli elementary schools. Elementary School Journal, 96, 184-185.

Guilfoyle, C. (2006, November). NCLB: Is there life beyond testing? Educational Leadership, 64 (3), 10-11.

Hoff, D. J. (2008, December). Schools struggling to meet key goal on Accountability. Education Week. Retrieved on line February 5, 2009, at http://www.edweek.org/ew/articles/2008/12/18.

Jazzar, M., \& Algozzine, B. (2006). Critical issues in educational leadership. Boston: Allyn-Bacon.

Klein, M.F. (2005). What imposed standards do to the child. In C.J. Marsh \& G.

Willis, Curriculum: Alternative approaches and ongoing issues. New Jersey: Pearson Education.

Marsh, C.J., \& Willis, G. (2007). Curriculum: Alternative approaches, ongoing issues. New Jersey: Pearson Education.

No Child Left Behind Act of 2001, Pub. L. No. 107-110, § 115 Stat, 1425 (2001).

Resnick, L. (2002). Learning leadership on the job. Wallace-Reader's Digest Funds Leader Count Report, 1 (2).

Sergiovanni, T.J. (2009). The principalship: A reflective practice perspective $\left(6^{\text {th }}\right.$ ed.). Allyn $\&$ Bacon: Boston.

Tyler, R. W. (1949). Basic principles of curriculum and instruction. The University of Chicago Press: Illinois. 